\title{
The Leadership Models of Principals to Alleviate Poverty at Lagging and Social Crisis Area in District of South-West Sumba, East Nusa Tenggara
}

\author{
T. Setiawaty, G. Tjahjono \\ Department of Technical and Vocational Education \\ Faculty Teacher Training and Education Science Nusa \\ Cendana University \\ Kupang, Indonesia \\ tettysetiawaty@gmail.com
}

\begin{abstract}
The purposes of the research were (1) to produce guideline models of principal leadership in alleviate of poverty at lagging and social crisis area in district of South-west Sumba East Nusa Tenggara; and (2) to produce indicator models of principal leadership to empower people through education. The method used Research and Development (R\&D), and data collection consisted of two stages, i.e. (1) pre-development stage, comprising: preliminary study, design and validation phase; and (2) development stage, comprising limited test, expended test, evaluation and revision phase. The subjects of this research were principals, vice principals and teachers of senior high school (SMA) and vocational high school (SMK) in South-west Sumba. The results of this research showed that the principals (1) applied the model of visionary leadership to alleviate poverty through education; (2) empowered people to improve learning quality; (3) involved community leaders, religious leaders and churches to increased student motivation; (4) involved churches and religious leaders in motivating student learning; and (5) involved community leaders in keeping schools and school facilities.
\end{abstract}

Keywords - Leadership principals, alleviate poverty, religious leaders, student motivation

\section{INTRODUCTION}

Southwest Sumba District (SBD) is a district expention of West Sumba district in East Nusa Tenggara, based on Law Number 162007 on the formation of the Southwest Sumba district. SBD has wide area $148.04 \mathrm{~km} 2$, or $36.53 \%$ of the total area of the West Sumba district. Most of the area is hilly and almost 50 percent of the total area has a slope of $14-40^{\circ}$. Hilly topography easily caused soil erosion [1].

SBD is the sixth province with the highest poverty rate in Indonesia. National Central Bureau of Statistics 2014 describes $23.03 \%$ population of East Nusa Tenggara is poor. The data has not changed significantly. In 2013 the poverty rate in East Nusa Tenggara reached $20.41 \%$. The data nearly twice the average national rate is $11.6 \%$. The value of the human development index (HDI) reached 67.75, causing NTT as one of the 18 provinces with 72.77 HDI below the national average [2][3].
SBD in 2013 was developed into eleven districts of the eight districts. Population increasingly dense caused by factors of young age marriage, polygamy and the motto many children make so much money is a motivation to have many children. The conditions resulted in lower quality education, while employment is limited, reduced agricultural product and health problems. This raises new social problems. The dropout rate is greater than the number of students. Poverty and economic needs, the cause of the increasing number of crimes such as theft and robbery [4]

SBD condition is described as undeveloped area. Un developed areas is areas that the community and the region undeveloped than other areas nationwide. Undeveloped area is caused by several factors: 1) the geographic relatively difficult to reach because it is located far inland, the hills/mountains, islands, making it difficult to reach by transportation and communication media; 2) the natural resources cannot be exploited for the welfare of the people; 3) human resources have a level of education, knowledge and skills is relatively low as well as traditional institutions underdeveloped; 4) communication, transportation, education, services facilities are lower caused to difficult social and economic activities; 5) isolated area, easily conflict and disaster-prone caused disruption of social and economic development activities.

\section{METHOD}

This research method is research and development (R \& D) with development of educational design by Richey \& Nelson and Plomp and some modification that include steps of research R \& D by Borg \& Gall.

Research procedures conducted two phases of activity: pre development and development phase. Pre-development phase development activities: (1) the initial investigation, activities are: analysis of leadership and analysis of Principal Leadership problem; (2) design, activities: formulating the kind of school leadership, formulating approaches to school leadership, formulating variables of school leadership, formulating development of research instruments, formulate 
research instruments to determine the principal's leadership is applied to the area lagging and social crisis; (3) Realization phase /construction. This phase produces a model instrument design leadership in senior high school (SMA) and vocational high school (SMK). The activities of development phase are: 1) the validity test conducted by a team of education experts and practitioners are teachers or principals; 2) small group test; 3) test expansion test. Phase development of the principal leadership can be seen in the following figure :

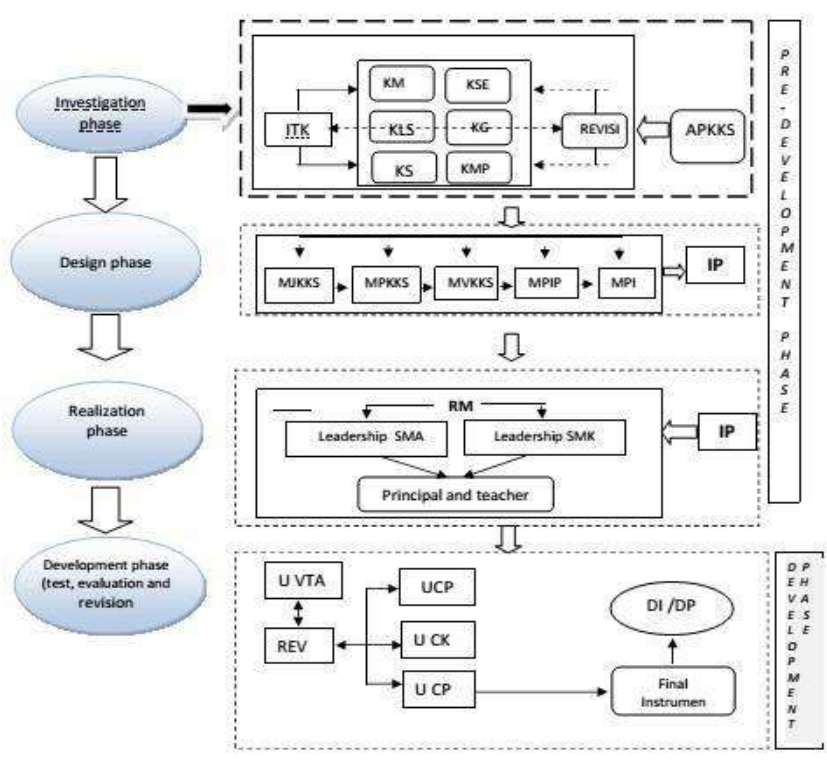

Fig-l. Principal Leadership Development Stages
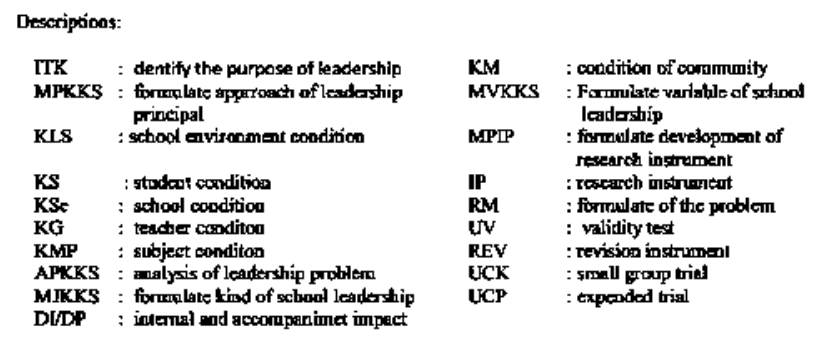

\section{A. Trial Products}

The test is done by: (1) the number of small group trial total of 32 samples were divided into SMA Weetebula 16 samples and 16 samples North Kodi. (2) the amount of expanded trial are 60 samples were divided into 30 samples SMA N 1 North Wewewa and 30 samples SMKN 2 North Wewewa. Subject are principals, vice principals and teachers.

Types of data collected are the quantitative and qualitative data. Quantitative data described in the instrument questions grouped into two variables: independent and dependent variables. Independent variabel are: visionary leadership model (X1), improve student learning interest (X21), increase student achievement (X2-1), improve performance teachers (X2-3), Empowering Communities through Education (X3-1) and increase student achievement motivation (X3-2). Dependent variables are: alleviating poverty through education, main duties and function of principal and profesional leadership principal. Qualitative data were collected through interviews, observation and documentation. Quantitative data were analyzed by SPSS version 18 .

\section{THE RESULT OF THE RESEARCH}

\section{Education in Southwest Sumba}

Southwest Sumba Regency (SBD) tried to improve its human resources (HR) through the development of education. Compulsory education program 9-years has been expanded into 12-year that people 7-15 age can participate in education on basic education. Specifically, the quality of the population can be seen by the percentage of population able to finish their education to a higher level. The following table describes the percentage of the total population based on the number of diploma-owned.

\begin{tabular}{|c|c|c|c|}
\hline Fiplom & $\mathbf{L}$ & $\mathbf{F}$ & $\mathbf{L} \nrightarrow \mathbf{P}$ \\
\hline Do nox the catificat & 53,97 & $51, \pi$ & 52,91 \\
\hline Elamentar schooldequisalnal & 28,00 & 25,49 & 24.73 \\
\hline Jmin tigh sthol & II, $\mathrm{R}$ & 12,14 & II,99 \\
\hline Serix bigh shod/fer wivent & 600 & 7,59 & 7,080 \\
\hline Yootimal hifh show & 2,02 & $1,0.4$ & 1,54 \\
\hline 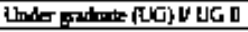 & 0,21 & 0,37 & 0,29 \\
\hline 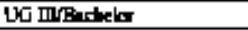 & 0,51 & 0,46 & ESA \\
\hline QE IVISIS2S3 & 0.84 & 1.12 & 0.98 \\
\hline
\end{tabular}

The data above describes the school participation rate (SPR) at SBD district the highest is the population aged 7-12 years means that the number of students of primary school age (ranked highest by number of $52.91 \%$. When stratified by sex, number of male students conduct more than female students. Data can be seen in the following table.

\begin{tabular}{|c|c|c|c|}
\hline 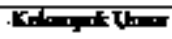 & $\mathbf{L}$ & $F$ & $\mathbf{L}+\mathbf{F}$ \\
\hline $3-12$ & 53,97 & $51, \pi 8$ & 5291 \\
\hline $33-15$ & 24,00 & 25,49 & $24 \pi$ \\
\hline $96-18$ & 31,84 & 12,14 & 11,98 \\
\hline 19.24 & 6,60 & 7,59 & 7,06 \\
\hline
\end{tabular}

The increasing number of primary and secondary school students require more number of teachers so that the learning process can run smoothly. Comparis on of the number of teachers and student are not sufficient impact on the supervision teacher to student.

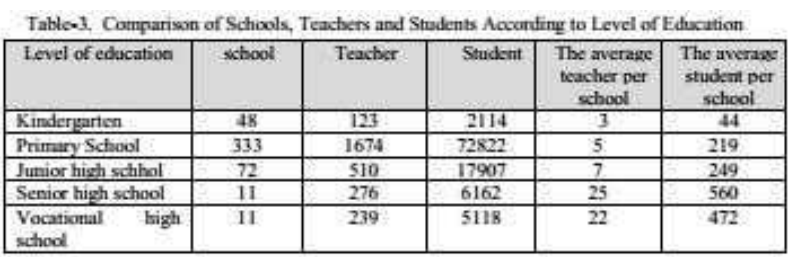

\section{A. The Principal Leadership}

Result Test Limited Test (small group)

- Poverty Alleviation Community $=42.495+0.937$ Visionary Leadership Model $(\mathrm{Y} 1=42.495+0.937 \mathrm{X})$; 
- Duties and Functions Principal $=17.189+0.252105$ increase interest in learning +2.143 improvement achievement learning +1.573 improving teacher performance $(\mathrm{Y} 2=17.189+0.252 \mathrm{X} 1+2.143 \mathrm{X} 2+$. $1,573 \mathrm{X} 3)$

- Principal as Leader Professional $=96.320-0.082$ empowering communities through education +0.528 increasing student motivation $(\mathrm{Y} 3=96.320-0.082 \mathrm{X} 1$ $+0.528 \mathrm{X} 2$ )

\section{B. Result Testing Expanded(Large Group)}

- Poverty Alleviation Community $=53,548+0,329$ Visionary Leadership Model. ( $\mathrm{Y} 1=53,548+0,329$ X).

- Duties and Functions Principal $=89,759+2,105$ increase interest in learning $+1,765$ improvement achievement learning - 0,288 improving teacher performance $(\mathrm{Y} 2=89,759+2,105 \mathrm{X} 1+1,765 \mathrm{X} 2-$ $0,288 \times 3)$.

- Principal as Leader Professional $=80,999+0,059$ empowering communities through education $+0,639$ increasing student motivation $(\mathrm{Y} 3=80,999+0,059 \mathrm{X} 1$ $+0,639 \times 2)$

\section{School Principal Guideline}

The product of this research is the Handbook of Leadership Principal (BPKKS). BPKKS made based on models that have been produced. The test results in a large group of data can answer 97\% agree with the items that exist in BPKKS. Based on the results of an existing presentation, BPKKS can be used as a guide for principals in implementing leadership in SMA and SMK, only 3\% who disagree of the items listed in the guidebook.

\section{Involve Churches and Religious Leaders in Motivating Student Learning}

Religious leaders are respected society. Every Sunday and religious Protestant and Catholic Christian pastors always remind the importance of learning for students and the community. Improve school attendance, homework, remind the importance of the school for the future to the attention of religious leaders and serve as the weekly sermon. Parents or community protest due to the actions of teachers to students who may not be directly to the school but completed at home pastor or religious leader. How this is done to secure the schooland teachers of students and community action.

\section{Involving Community Leaders in Keeping Schools and Schools Facilities}

Schools damaged by thrown by people who are irresponsible and school facilities and infrastructure of learning often stolen. This is very detrimental to the school and students. To overcome the problems of school safety, school principals involve community leaders around the school to keep the school from damage and theft, which are paid through the schoolcommittee money every month.
The triangular relationship between the school, community and church leaders can be seen in the picture below.

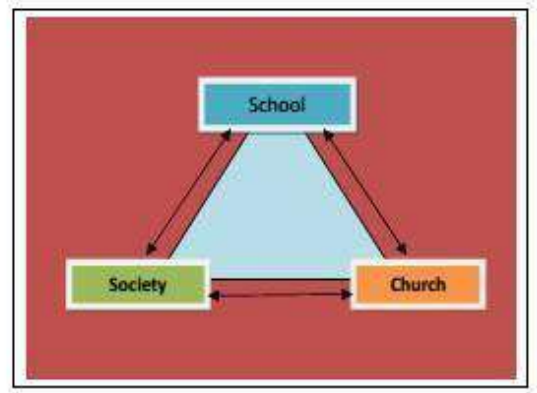

Fig. 2. The triangular relationship between school, community and church leaders

\section{CONCLUSIONS}

- Education can improve the quality of human resources development building and alleviate poverty and unemployment.

- Visionary leadership is a leadership model which appropriate used to lead schools with cultural diversity and community issues.

- The results showed: (1) visionary leadership model affect on the poverty alleviation community; (2) applying the duties and functions of the school principal influence on the increase in student interest and increase student achievement and teacher performance improvement; (3) principal as professional leader is very influential on improving student learning motivation but less effect on community empowerment through education.

- School Principal guideline can be used to lead the SMA and SMK with lagging regions and social crisis conditions.

- the triangular relationship between the school, community and church leaders can increase learning motivation, learning interest, student and school achievement and improving teacher performance and maintaining school infrastructure.

\section{ACKNOWLEDGMENT}

The authors would like to thank the principal Nort Wewewa and Alfonsus Senior High School, Right Wewewa and Nort Kodi Vocational High School, which has research is done, and the Directorate of Higher Education, Ministry of Research, technology and higher education of the Republic Indonesia, which has provided funding of this research.

\section{REFERENCES}

[1] Nusa Tenggara Timur. 2013 (http://infonusa tenggara timur.html).

[2] Bappeda Kabupaten Sumba Barat Daya. 2014. Tinjauan Kesejahter aan Sosial Sumba Barat Daya. Kerjasama Badan Pusat Statistik. 
[3] Saleh, Rahmayus diambil dari http://m.bisnis.com/quick-news/read /20140430/78/223465/sumba-barat-terus-berupaya-bangkitdarikemiskinan).

[4] (http://cserbaserbi.blogspot.com/2013/06/makalah-multikulturalsumbabarat -daya.html). 